\title{
EFFECT OF INDUSTRIAL WASTEWATER ON FISH IN KAROON RIVER
}

\section{Zahra KHOSHNOOD * and Reza KHOSHNOOD **}

* Islamic Azad University, Faculty of Science, Department of Experimental Sciences, University Boulevard, Dezful, Iran, P. O. Box 313, IR-64618-57518, ZKhoshnood@gmail.com

** Islamic Azad University, Science and Research Branch, Daneshgah Boulevard, Hesarak Tehran, Iran, IR-14515-775, RezaKhoshnood@gmail.com

KEYWORDS: Industrial wastewater, fish, Karoon River.

\section{ABSTRACT}

In 2009, 36 fish were sampled from two stations in the Karoon River near an industrial site. Two species of fish, Barbus grypus and Hypophthalmichthys molitrix were analyzed for total mercury $(\mathrm{Hg})$ concentration in liver and muscle tissues. The average concentrations of total $\mathrm{Hg}$ in liver of B. grypus were 18.92 and $10.19 \mu \mathrm{g} \cdot \mathrm{g}^{-1}$ in stations 1 and 2 respectively. The corresponding values for total $\mathrm{Hg}$ in edible muscle of Barbus grypus were 8.47 and $0.08 \mu \mathrm{g} . \mathrm{g}^{-1}$. The average concentrations of $\mathrm{Hg}$ in the liver of $\mathrm{H}$. molitrix were 25.49 and 12.52 $\mu \mathrm{g} . \mathrm{g}^{-1}$ in stations 1 and 2 respectively. The values for $H$. molitrix were 11.88 and $3.2 \mu \mathrm{g} . \mathrm{g}^{-1}$ in station 1 and station 2 respectively. The results showed that the bioavailability of $\mathrm{Hg}$ has increased considerably after industrialization and that these values were higher than the standard values as a result of anthropogenic activities in the region.

ZUSAMMENFASSUNG: Auswirkungen von Industrie-Abwässern auf die Fische im Karoon-Fluss.

Während des Jahres 2009 wurden 36 Fischarten von zwei Standorten im Karoon-Fluss nahe der Industrieanlage erfasst. Zwei Arten Barbus grypus und Hypophthalmichthys molitrix wurden im Hinblick auf die Gesamtkonzentration von Quecksilber in Leber und Muskeln untersucht. Die durchschnittliche Konzentration des Gesamt-Quecksilbers in der Leber von $B$. grypusbetrug $18.92 \mu \mathrm{g} . \mathrm{g}^{-1}$ an Probestelle 1, beziehungsweise $10.19 \mu \mathrm{g} \cdot \mathrm{g}^{-1}$ an Probestelle 2. Die entsprechenden Werte für das Gesamtquecksilber in essbaren Muskeln von Barbus grypus waren 8.47 and $0.08 \mu \mathrm{g} \cdot \mathrm{g}^{-1}$. Die durchschnittliche Konzentration von Quecksilber in der Leber von H. molitrix betrug $25.49 \mu \mathrm{g} . \mathrm{g}^{-1}$ am Porbestandort 1 und $12.52 \mu \mathrm{g} . \mathrm{g}^{-1}$ am Probestandort 2, während die Werte in essbaren Muskeln der Art $11.88 \mu \mathrm{g} . \mathrm{g}^{-1}$ an Probestelle 1 und $3.2 \mu \mathrm{g} . \mathrm{g}^{-1}$ an Probestelle 2 betrugen. Die Ergebnisse zeigen, dass die biologische Verfügbarkeit nach der Industrialisierung beachtlich angestiegen ist und dass diese Werte bedingt durch die anthropogenen Tätigkeiten in der Region höher liegen als die Standardwerte.

REZUMAT: Efectul apelor industriale uzate asupra peștilor din râul Karoon.

În 2009, 36 de probe de pești au fost recoltate din două stații ale râului Karoon în apropierea zonei industriale. Două specii de Barbus grypus și Hypophthalmichthys molitrix au fost analizate în ceea ce privește concentrația totală de $\mathrm{Hg}$ din ficat și muşchi. Concentrația medie de Hg în ficatul speciei $B$. grypus a fost 18,92 și $10,19 \mu \mathrm{g} \cdot \mathrm{g}^{-1}$ în stația 1 și respectiv 2. Valorile corespondente de $\mathrm{Hg}$, pentru această specie, în mușchi au fost 8,47 și $0,08 \mu \mathrm{g} \cdot \mathrm{g}^{-1}$. Concentrația medie de $\mathrm{Hg}$ în ficatul speciei $H$. molitrix a fost 25,49 și 12,52 $\mu$ g.g g $^{-}$in stația 1 și respectiv 2. În ceea ce privește specia $H$. molitrix valorile înregistrate au fost de $11,88 \mu \mathrm{g} \cdot \mathrm{g}^{-1}$ în stația 1 și 3,2 $\mu \mathrm{g} \cdot \mathrm{g}^{-1}$ în stația 2. Rezultatele au arătat că biodisponibilitatea elementului $\mathrm{Hg}$ a crescut considerabil după industrializare, aceste valori fiind mai ridicate decât valorile standard datorită nivelului ridicat de activitate antropică din zonă. 


\section{INTRODUCTION}

Heavy metals such as mercury (Hg) are natural trace components of the aquatic environment. They cause serious alterations in metabolic, physiological and structural systems of living organisms when present in high concentration (Iliopoulou and Kotsanis, 2001), and induced health risks in sea food (Khoshnood and Khoshnood, 2013). Coastal fish species such as flat fish have been proposed as sentinel species to assess the possible effect of anthropogenic activities on a coastal area and for monitoring marine environment pollution (Eastwood and Couture, 2002), because fish are often at the top of the aquatic food chain and may concentrate large amounts of some metals from water (Mansour and Sidky, 2002). Tissues such as liver, kidney, muscles, viscera and whole organisms are typically analyzed to determine the concentration of the metals (Olifa et al., 2004).

In some cases, fish catches have been banned for human consumption because their total mercury content exceeded the maximum limits recommended by the Food and Agriculture/World Health Organization (Emami Khansari et al., 2005; FAO/WHO, 1972). Human sources of mercury include industrial wastewater, use of fossil fuels, fungicides and burning of waste (Hernandez et al., 1999).

Pollution studies in the Persian Gulf area collectively known as ROPME Sea Area (RSA) are extremely important. The Persian Gulf is relatively shallow, semi-enclosed with very high evaporation rates and is characterised by low flushing of waters (Mora et al., 2004a). Thus, any pollution discharge into the sea has limited opportunity for dilution and disperses more slowly than in other, more open marine systems (Shepperd, 1993). Moreover, the region relies heavily upon the seawater itself as a source of freshwater through desalination processes (Mora et al., 2004a).

Ongoing industrial development in the region, albeit geographically variable, continues to cause concern with respect to marine environmental quality. Unfortunately, regional information on heavy metal presence is not uniformly available. Agriculture, mostly located in the northern zone, is expanding in the region, bringing a threatened increase of emissions of pesticides and other agrochemicals, including heavy metal-based formulations (Fowler et al., 2002).

This study is a response to the to the lack of any comprehensive data on the Hg content of fish from this part of the Persian Gulf, and the considerable global concern about mercury contamination of commercial and subsistence fisheries products. In this paper, we will describe a new mercury analytical method that is a rapid and reliable technique, requiring minimum analysis time, and which is suitable for the routine analysis of large numbers of fish samples. The proposed method offers a fast and simple approach to sample digestion, dilution, and mercury determination for low concentrations in fish. In this study, the technique is applied for the first time in this region.

The aim of this study is to develop a rapid method for bio-monitoring studies of heavy metal pollution in the marine environment, in particular, to determine the total content of $\mathrm{Hg}$ in fish collected from various sampling points of the Persian Gulf, since these fish are an important component of the human diet in these regions.

It is hoped that the results of this study will help scientists generate data needed for the assessment of mercury intake from fish. Such data will be needed for the development of public health advisory guidelines on consumption. 


\section{MATERIAL AND METHODS}

\section{Selection of the study area and sample collection}

Fish samples were collected along two stretches of the Karoon River, in the southwest of Iran. Thirty-six fish specimens including Barbus grypus and Hypophthalmichthys molitrix were caught from April to June 2009. These two species were collected from two sample sites, one a wastewater discharge location (station 1) and the other about two kilometres upstream of a wastewater discharge location along the Karoon River (station 2).

\section{Analysis Procedure}

Immediately after the collection, fish samples were stored on ice in an isolated box (Eaton et al., 1995) and transferred to the Environmental Laboratory. Body weight and length of the fish were measured and the sex was determined. Male fish were then selected and a part of the dorsal muscle from each was dissected as a sample. The fish liver tissue was also removed and prepared for processing. All of the samples were dried at $600^{\circ} \mathrm{C}$ for $48 \mathrm{~h}$ in an oven (Gregory et al., 2005).

Total mercury was measured using an LECO AMA254 Advanced Mercury Analyzer (USA) according to ASTM, standard no. D-6722. Each sample was analyzed three times. The LECO AMA 254 is a unique Atomic Absorption Spectrometer (AAS) that is specifically designed to determine total mercury content in various solids and certain liquids without sample pre-treatment. Designed with a front-end combustion tube that is ideal for the decomposition of matrices, the instrument's operation may be divided into three phases during any given analysis: decomposition, collection, and detection.

To assess the analytical capability of the proposed methodology, accuracy of total $\mathrm{Hg}$ analysis was tested with reference matrices of dogfish liver tissue (DOLT 3), and muscle tissues (DORM 2). The results confirmed that the observed and reference values were not statistically different $(\mathrm{P}<0.05)$ (Tab. 1).

Table 1: Obtained and certified concentration ( $\mu g \cdot \mathrm{g}^{-1}$ dry weight) in certified reference materials.

\begin{tabular}{|c|c|c|}
\hline CRM & & HG \\
\hline DORM-1 & Certified & $0.789 \pm 0.074$ \\
\hline & Obtained & $0.0791 \pm 0.027$ \\
\hline DORM-2 & Certified & $4.64 \pm 0.26$ \\
\hline & Obtained & $4.60 \pm 0.22$ \\
\hline
\end{tabular}

\section{Statistical analysis:}

The statistical analyses were done using SPSS software (Version 11.5). The data were tested to check the normality using the Kolmogorov-Smirnov test, which showed that they are normally distributed. Pearson's correlation test was used to assess any significant relationship of concentration in tissue with fish length and weight in the two regions studied (level of significance, $(p<0.05)$ ). In addition, paired sample t-tests were used to compare mercury concentration between stations. 


\section{RESULTS AND DISCUSSION}

\section{Weight, Length and Sex}

The length of Barbus grypus individuals caught from station 1 were within the interval range of 24.5-36.5 cm; and from station 2 were between 24-41 cm. Results for Hypophthalmichthys molitrix, in station 1 showed a range length of 39 to $58 \mathrm{~cm}$ and in station 2 lengths ranged between $31.5-51 \mathrm{~cm}$.

All of the fish sampled in this study were male. The average measured size and weight of each sample are given below (Tab. 2).

Table 2: Fish sample biometry measurements; ${ }^{*} 1=$ below discharge point, ${ }^{* *}$ ST2 = above discharge point.

\begin{tabular}{|l|c|c|c|c|c|c|}
\hline Species & Station & No. of & \multicolumn{2}{|c|}{ Length $(\mathrm{cm})$} & \multicolumn{2}{c|}{ Weight (g) } \\
\cline { 4 - 7 } & & samples & Range & Mean \pm Std & Range & Mean \pm Std \\
\hline \multirow{2}{*}{$\begin{array}{l}\text { grypus } \\
\text { gryyyyy}\end{array}$} & $1^{*}$ & 6 & $24.5-36.5$ & $32.3 \pm 4.2$ & $240-710$ & $585 \pm 186$ \\
\cline { 4 - 7 } & $2^{* *}$ & 6 & $24-41$ & $32.1 \pm 6.3$ & $209-1,010$ & $604 \pm 302$ \\
\hline $\begin{array}{l}H . \\
\text { molitrix }\end{array}$ & 1 & 6 & $39-58$ & $48.1 \pm 7.5$ & $754-2,650$ & $1,672 \pm 760$ \\
\cline { 3 - 7 } & 2 & 6 & $31.5-51$ & $43.0 \pm 6.9$ & $497-2,286$ & $1,309 \pm 649$ \\
\hline
\end{tabular}

\section{Total mercury concentration in Muscle and Liver}

Table 3 presents the concentration range, mean and standard deviation of mercury based on dry weight ( $\mu \mathrm{g} \cdot \mathrm{g}^{-1}$ ) in muscle and liver of tissues from Barbus grypus and Hypophthalmichthys molitrix from the two sampling areas. The maximum mercury concentration was measured in station 1 (i.e. below the waste-water discharge point) in liver samples of Hypophthalmichthys molitrix $\left(25.48 \mu \mathrm{g} \cdot \mathrm{g}^{-1}\right)$, and the minimum concentration of mercury was noted in the muscle of Barbus grypus in station 2 (i.e. above discharge point) $\left(0.08 \mu \mathrm{g} \cdot \mathrm{g}^{-1}\right)$.

Table 3: Hg concentration of Barbus grypus and Hypophthalmichthys molitrix tissues; ${ }^{*}$ St $1=$ Station $1,{ }^{* *}$ St $2=$ Station 2.

\begin{tabular}{|c|c|c|c|c|c|}
\hline Species & tissues & \multicolumn{2}{|c|}{ Range } & \multicolumn{2}{c|}{ Mean \pm std } \\
\cline { 3 - 6 } & & St1 $^{*}$ & St2 $^{* *}$ & St1 $^{*}$ & St2 $^{* *}$ \\
\hline $\begin{array}{c}\text { B. } \\
\text { grypus }\end{array}$ & liver & $8.8-15.25$ & $0.77-5.77$ & $11.88 \pm 2.46$ & $3.2 \pm 1.75$ \\
\cline { 2 - 6 } & muscle & $5.28-14.15$ & $0.04-2.75$ & $8.47 \pm 4.31$ & $0.081 \pm 1.02$ \\
\hline $\begin{array}{c}H . \\
\text { molitrix }\end{array}$ & liver & $16.57-31.26$ & $4.26-19.56$ & $25.49 \pm 5.82$ & $12.52 \pm 5.41$ \\
\cline { 2 - 6 } & muscle & $10.24-25.25$ & $1.53-16.64$ & $18.92 \pm 5.99$ & $10.19 \pm 5.26$ \\
\hline
\end{tabular}

Various studies of coastal environments have shown that accumulation of $\mathrm{Hg}$ in several organisms varies along a concentration gradient of anthropogenic $\mathrm{Hg}$ (Coelho et al., 2005).

Hg concentration in samples of muscle and liver of Barbus grypus in the two stations were shown to be significantly different $(\mathrm{p}<0.05)$. The same results were founded in Hypophthalmichthys molitrix, maybe because station 1 is an industrial region, with many large factories dealing with petrochemical, oil and gas extraction and transportation, agriculture, production and pesticides. 
A significant positive correlation between body weight and length was found in all fish samples ( $<<0.01$ or $\mathrm{p}<0.05$ ) (Figs. 2-4). These relationship are in line with various studies (Branco et al., 2004; Pinho et al., 2002) that demonstrate an increase of Hg levels in muscular tissues of aquatic organisms with age, to which length is assumed to be directly related (Branco et al., 2004). For instance in figure 1 (station 1), concentration of $\mathrm{Hg}$ in muscle and liver shows very positive correlation at R2 0.764 for liver and R2 0.815 for muscle in Barbus grypus. The same relation can be seen for station 2 (Fig. 2).

Significant positive correlations were observed between body weight and $\mathrm{Hg}$ concentration in liver and muscle $(\mathrm{p}<0.05)$ in the two fish species, at both stations. A significant positive correlation with body length was likewise found for $\mathrm{Hg}$ in liver tissues of the two species $(\mathrm{p}<0.01)$ at both stations, and similarly, muscle also demonstrated a positive correlation for both species at both stations $(\mathrm{p}<0.05)$.

Generally, the growth-dependent variation of trace element level (and $\mathrm{Hg}$ level) is known to be influenced by various factors such as metabolic rate and growth dilution of the element (Langston and Spence, 1995). The increased fish Hg concentrations demonstrated here suggest that the bioavailability of $\mathrm{Hg}$ has increased considerably after industrialization. This is probably the result of increased $\mathrm{Hg}$ methylation due to the increased concentration of dissolved organic carbon and reduced concentration of dissolved oxygen, and the discharge of $\mathrm{Hg}$ from petrochemical activities in these regions. Alternatively, $\mathrm{Hg}$ could have been released into the water, attached to suspended or dissolved organic matter, as a result of increased decomposition of organic material from flooded land. Increased decomposition in combination with a deeper water column creates anoxic conditions favouring $\mathrm{Hg}$ methylation. Increased methyl-Hg accumulation and biomagnifications in food webs occurs particularly in fish, as these species are often at the top of the food chain. These species are also popular for human consumption, and therefore may pose a threat to the health of populations dependent on fishing in the actual coastal zone for sustenance. It is important to create awareness of $\mathrm{Hg}$ health effects linked to consumption of different fish species by improving the information available to the local population.

For comparison, within this region, Hg levels have been observed to vary between 0.19 and $2.34 \mu g . g^{-1}$ in coastal sediments from Doha, Qatar (Al-madfa et al., 1994). The highest concentration of $\mathrm{Hg}\left(2,035 \mu \mathrm{g} . \mathrm{gr}^{-1}\right.$ dry or $0.49 \mu \mathrm{g} \cdot \mathrm{gr}^{-1}$ wet $)$ in muscle was measured in a grouper from Al-Madfa in UAE, and only just approached $0.5 \mu \mathrm{ggr}^{-1}$ wet weight, a level considered by many countries to be the upper acceptable limit for consumable fish, including for instance Saudi Arabia. Studies from the Persian Gulf and the Gulf of Oman in 2004 found mercury concentrations in the muscle and liver of grouper varied in the ranges 0.50-2.35 and $0.287-4.65 \mu \mathrm{g} \cdot \mathrm{gr}^{-1}$ respectively - comparable with the results presented here. Mercury is recognized as one of the most important bioaccumulated metals in fish (Mora et al., 2004b).

On the other hand, the Gulf of Trieste in Italy is exceedingly polluted due to historic cinnabar mining in the catchment region, with total Hg ranging from 0.064 to $30.38 \mu \mathrm{g} . \mathrm{g}^{-1}$ and averaging $5.04 \mu \mathrm{g} . \mathrm{gr}^{-1}$ (Covelli et al., 2001).

When the data from this study are compared with findings from Gaspic et al. (2002) and Kucuksezgin et al. (2002), it is notable that the present results show higher $\mathrm{Hg}$ concentrations in the liver compared with other body regions. Liver tissues are often recommended as the best environmental indicator of water pollution over any other fish organs. This is possibly attributed to the tendency of liver to accumulate pollutants of various kinds at higher levels from their environment. 


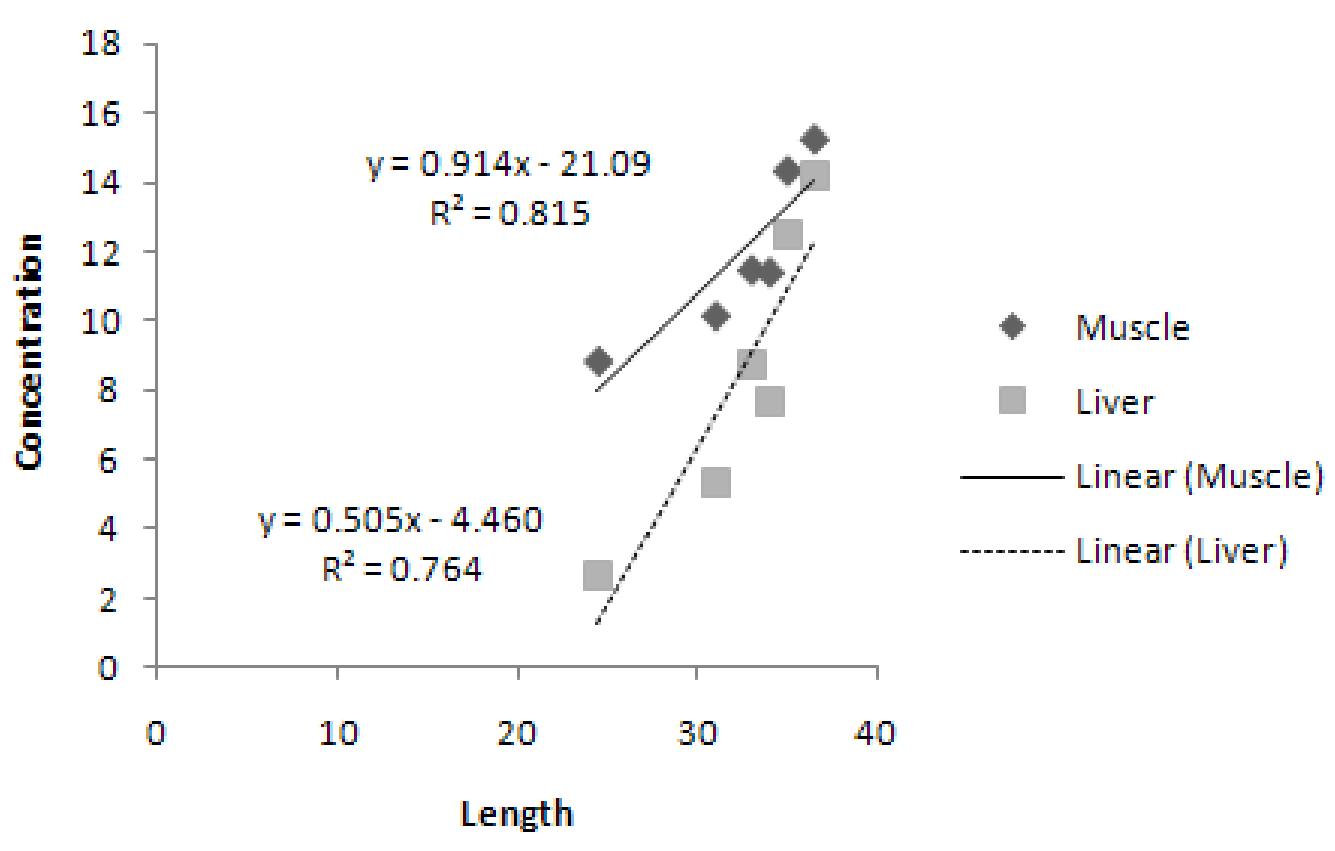

Figure 1a: Relationship between Hg concentration, length and weight on Barbus grypus in station 1.

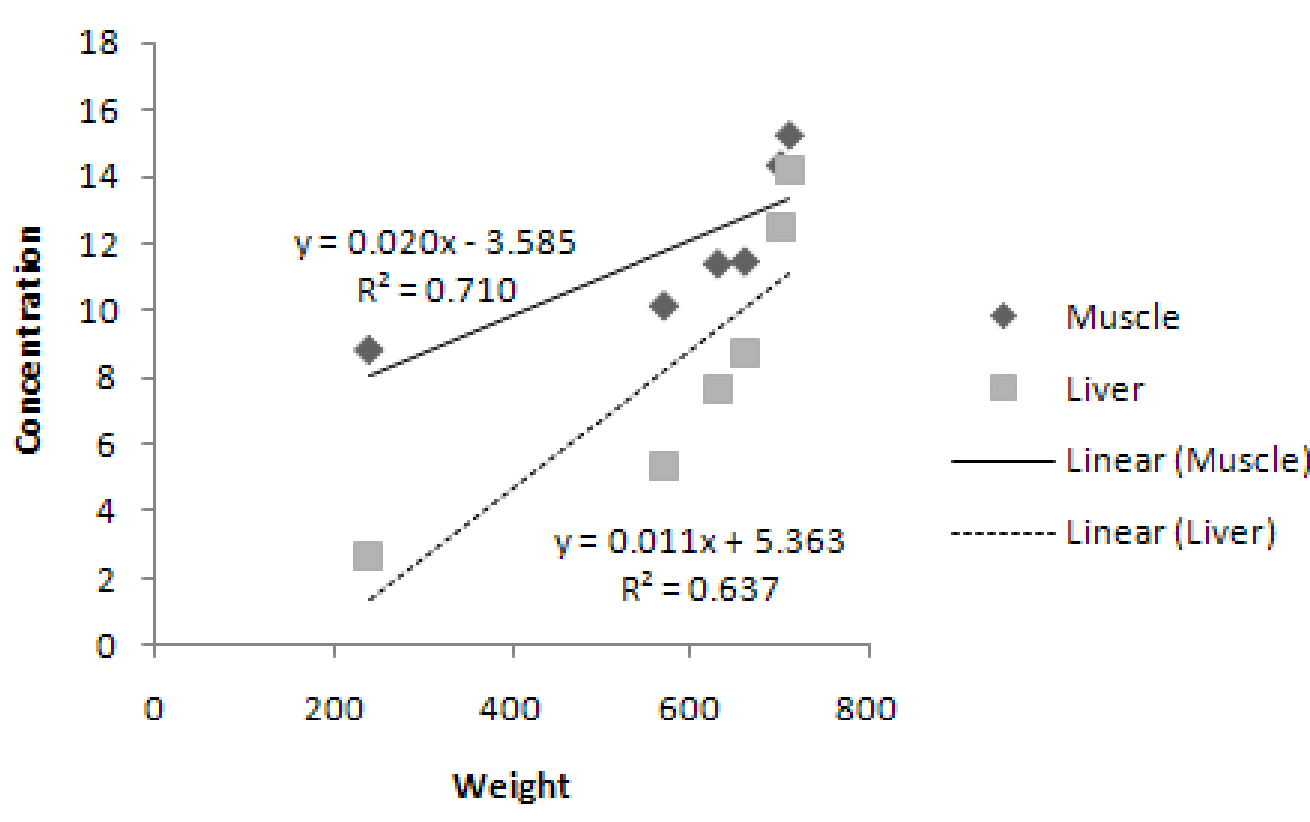

Figure 1b: Relationship between Hg concentration, length and weight on Barbus grypus in station 1. 


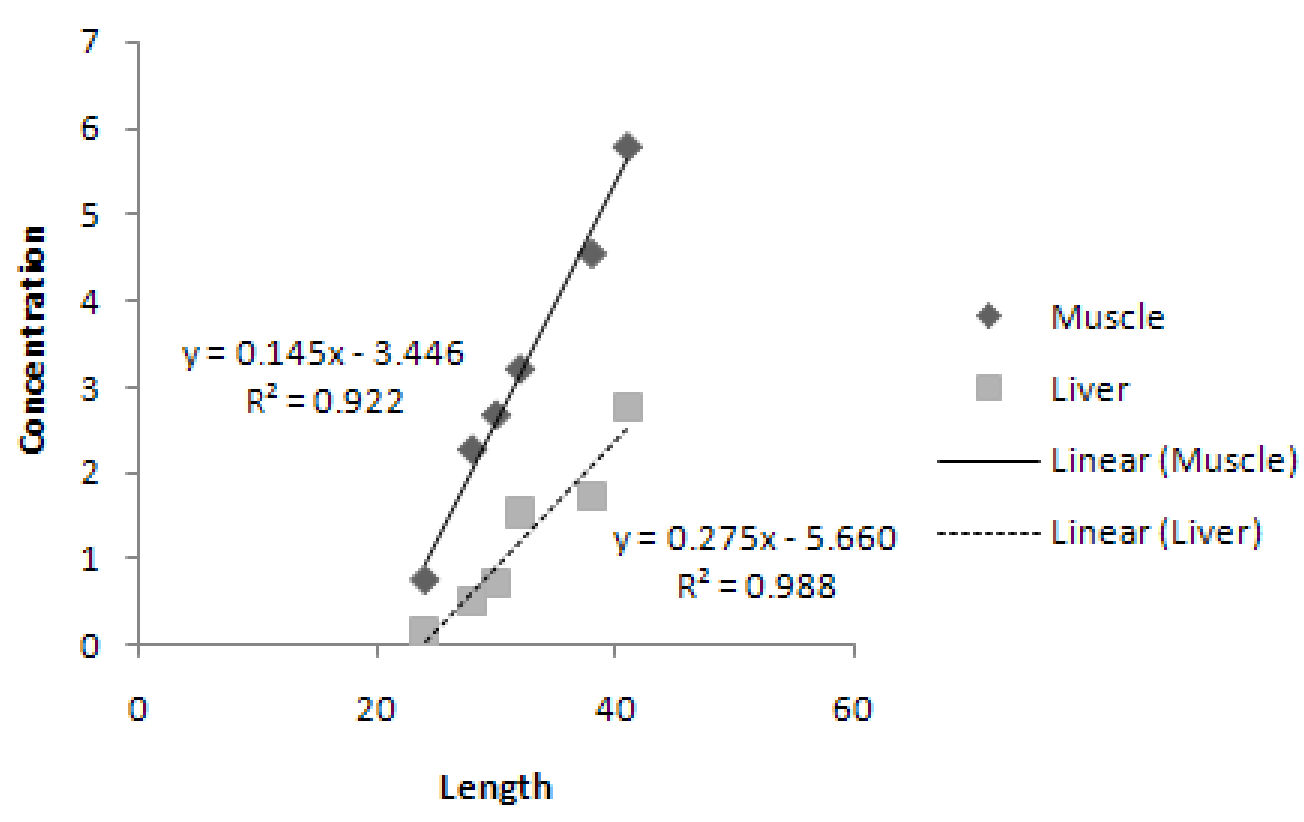

Figure 2a: Relationship between Hg concentration, length and weight in Barbus grypus in station 2.

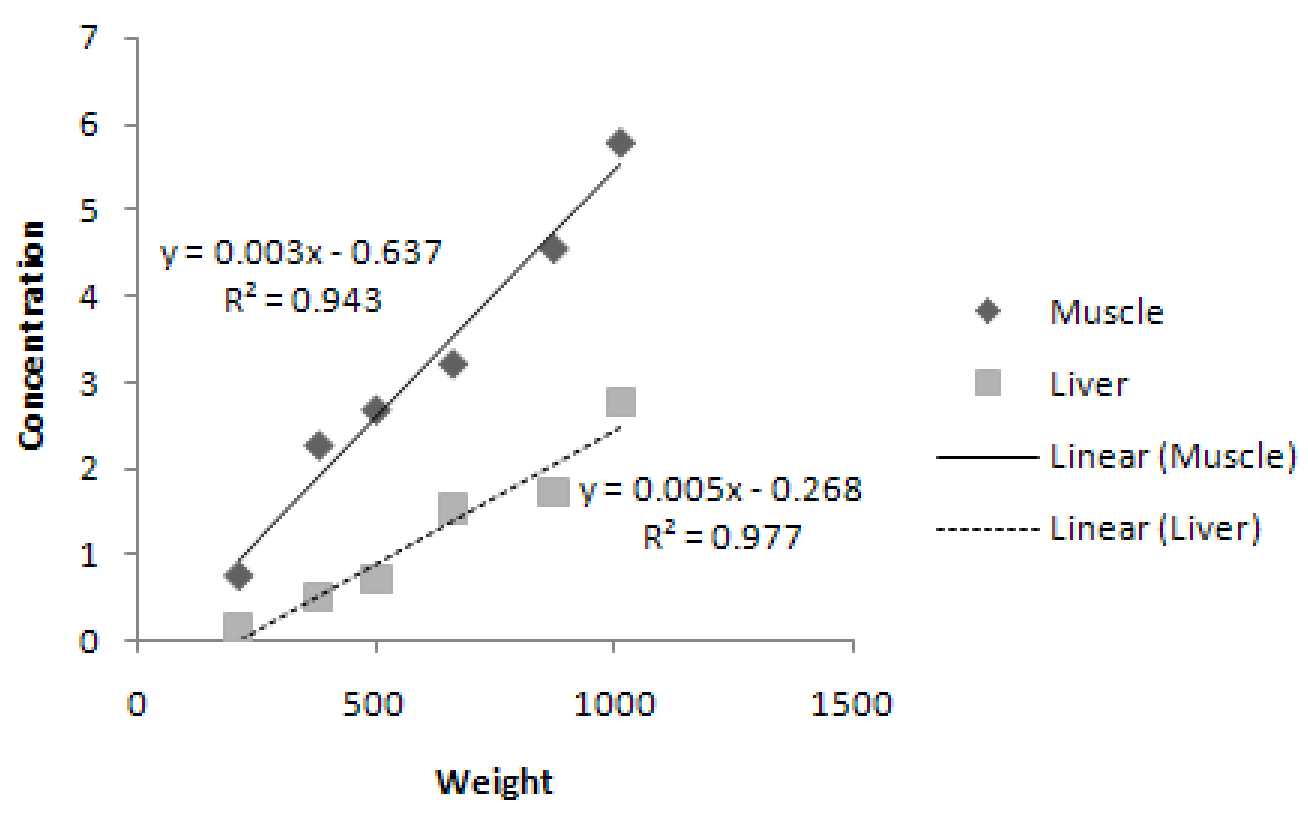

Figure 2b: Relationship between Hg concentration, length and weight in Barbus grypus in station 2. 


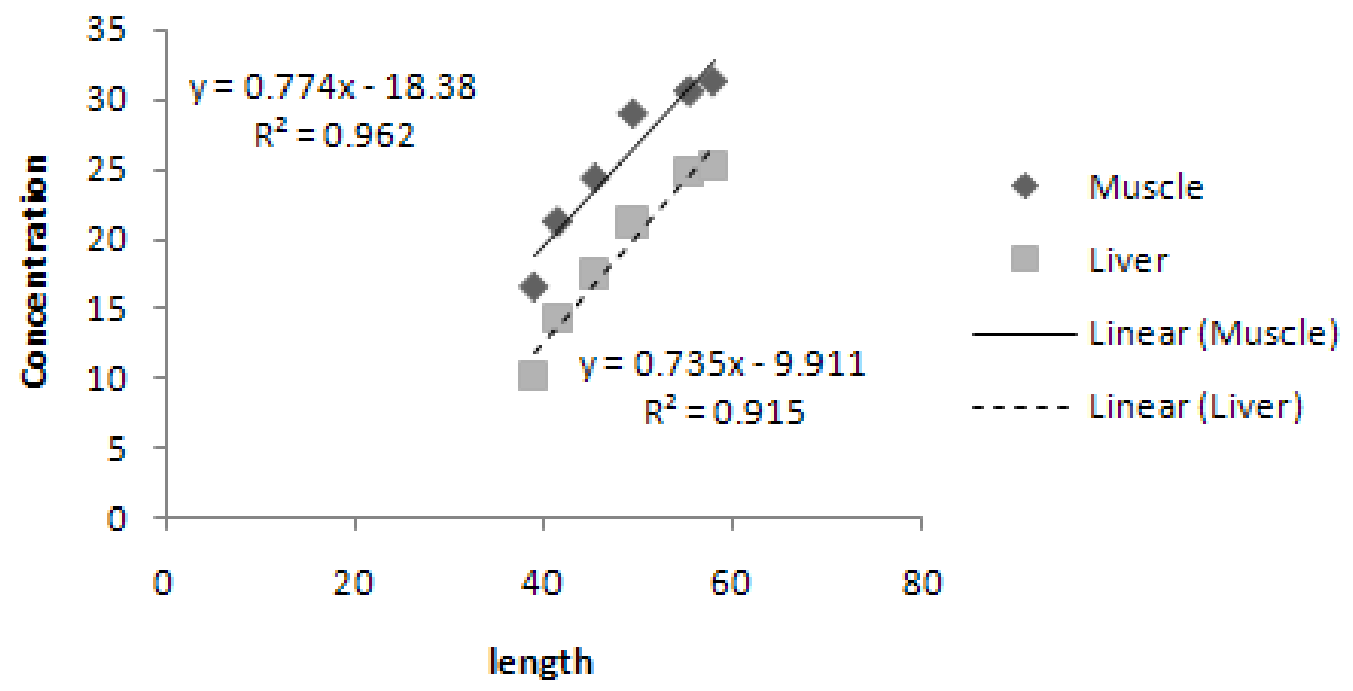

Figure 3a: relationship between Hg concentration, length and weight in Hypophthalmichthys molitrix in station 1.

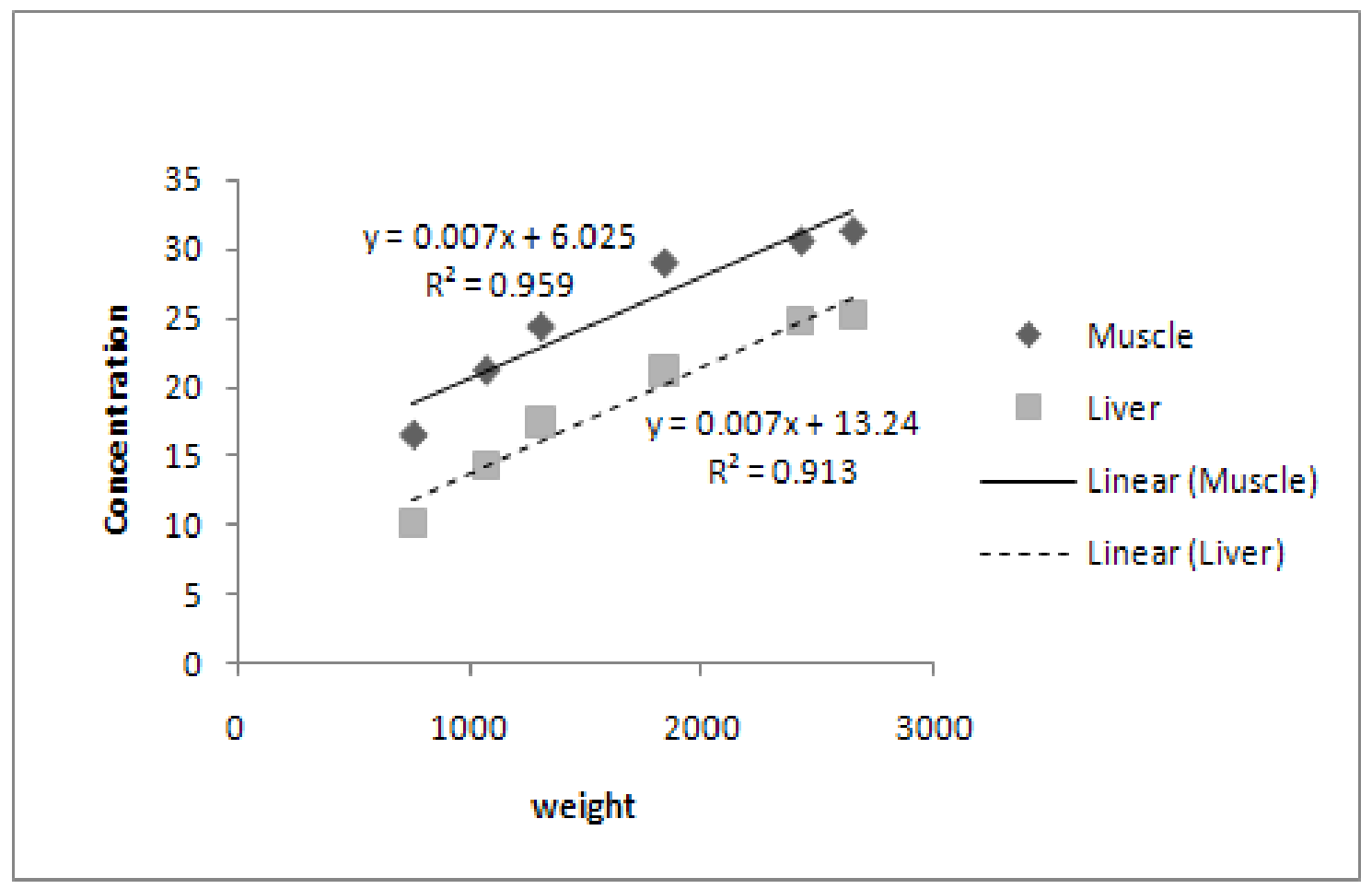

Figure 3b: relationship between Hg concentration, length and weight in Hypophthalmichthys molitrix in station 1. 


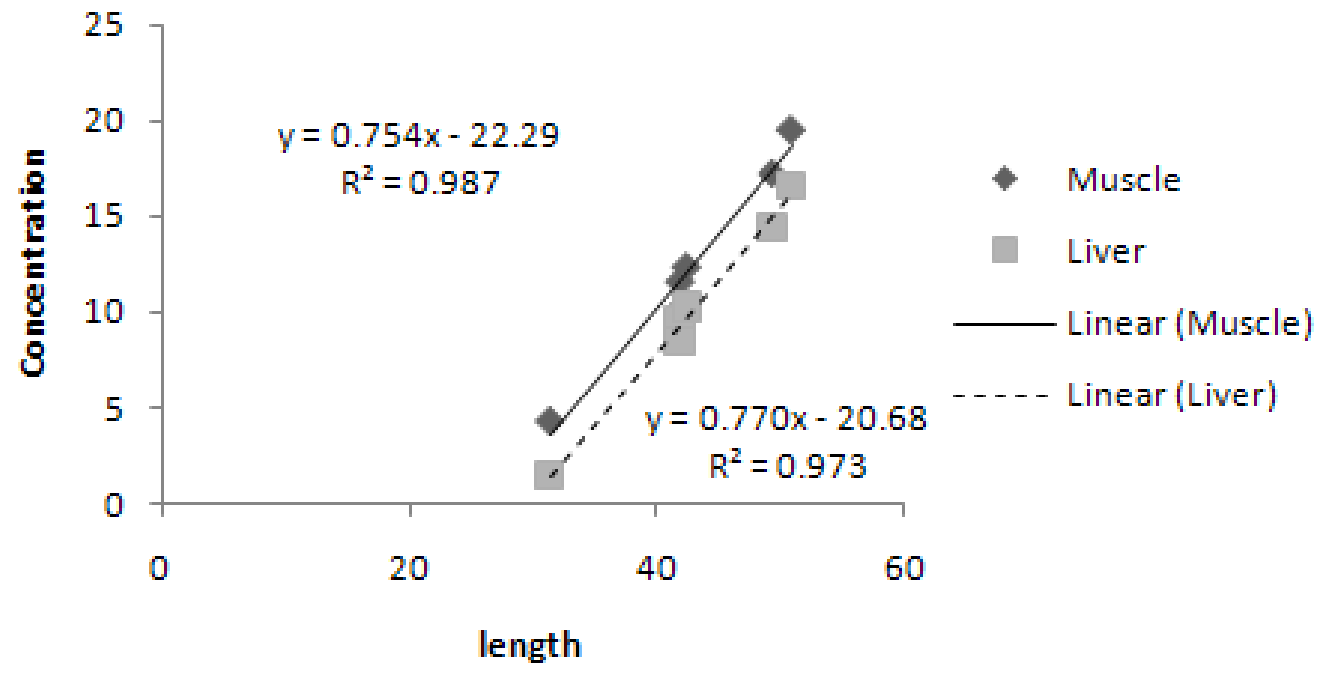

Figure 4a: Relationship between Hg concentration, length and weight in Hypophthalmichthys molitrix in station 2.

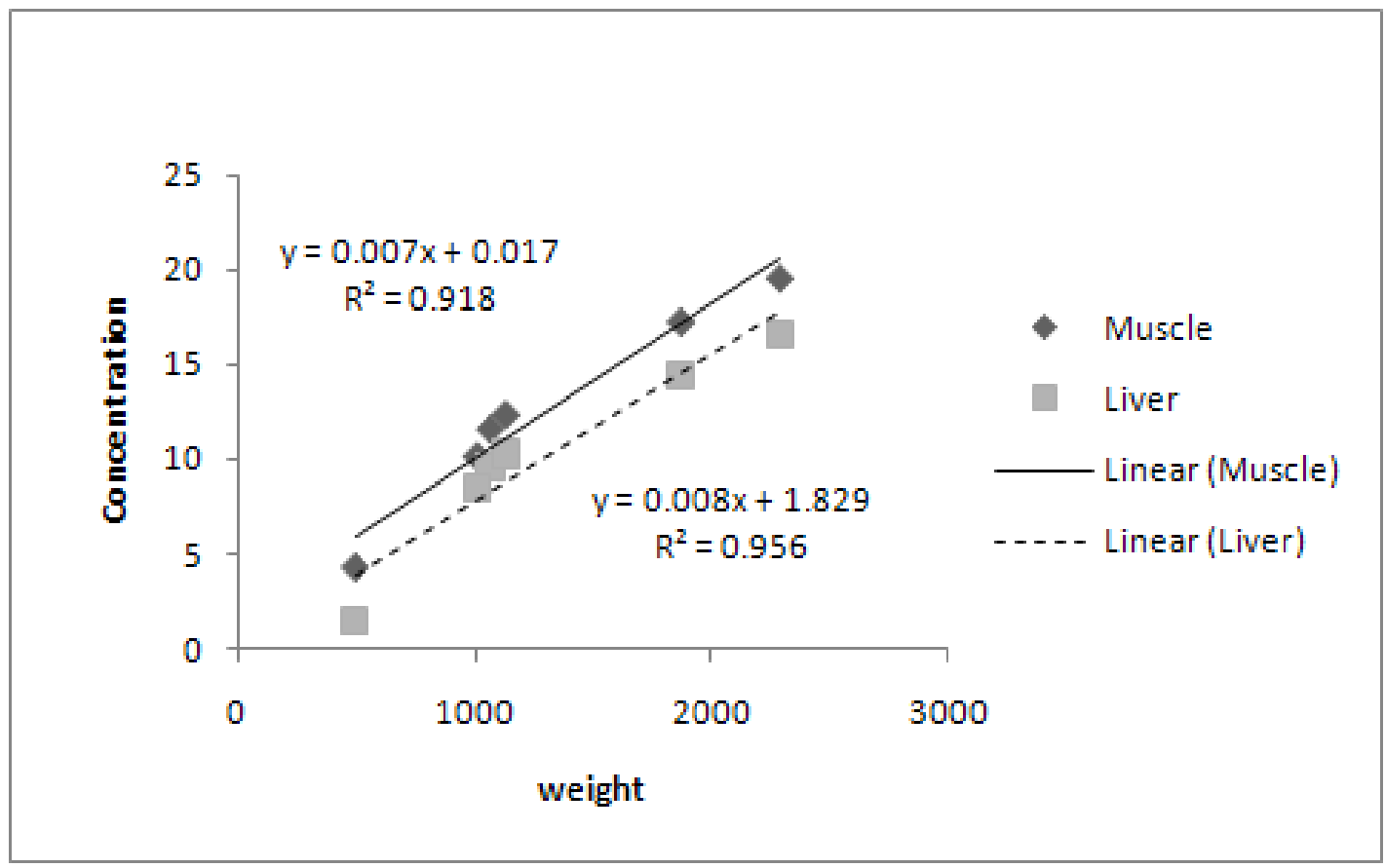

Figure 4b: Relationship between Hg concentration,

length and weight in Hypophthalmichthys molitrix in station 2. 
Other studies on heavy metal content investigated different organ tissues of Red Pandora (Pagellus erythrinus) from the eastern Aegean Sea between May 1996 and July 1998, demonstrating that concentrations of mercury in muscle tissues ranged from 16 to $716 \mathrm{~g}_{\mathrm{kg}} \mathrm{k}^{-1}$, in the liver between 125-5,451 g. $\mathrm{kg}^{-1}$, and in the gonad 2.0-1,858 g. $\mathrm{kg}^{-1}$ (Uluturhan and Kucuksezgin, 2007).

Therefore, diets relying heavily on fish could be the main source of exposure to mercury in the general population. More have to be done on public advisory advice on fish consumption and government control of pollutants in the area.

\section{CONCLUSIONS}

The results of this study provide a basis for the assessment of human exposure to mercury from fish collected from the Kaloon River, Iran. The concentration of mercury in the fish samples observed in this study is high when compared to some other areas of the world, especially when compared to non-polluted areas of the world. The pollution observed here is the result of anthropogenic activities such as petrochemical industries, agricultural pesticides, oil extraction and transportation, and sunken ships, amongst other causes.

\section{ACKNOWLEDGEMENTS}

We would like to express our special thanks to Hossein Pasha, who kindly assisted us in data analysis and we are also grateful to Afkhami M. and Ehsanpour M. for their help during fish sampling and sample analyses. 


\section{REFERENCES}

1. Al-Madfa H., Dahab O. A. and Holail H., 1994 - Mercury pollution in Doha (Qatar) coastal environment, Environmental Toxicology, 13, 725-735.

2. Branco V., Canario J., Vale C., Raimundo J. and Reis C., 2004 - Total and organic mercury concentrations in muscle tissue of the blue shark (Prionace glauca L. 1758) from the Northeast Atlantic, Marine Pollution Bulletin, 49, 854-874.

3. Coelho J. P., Pereira M. E., Duarte A. and Pardal M. A., 2005 - Macro algae response to a mercury contamination gradient in a temperate coastal lagoon (Ria de Aveiro, Portugal), Estuarine, Coastal and Shelf Science, 65, 492-500.

4. Covelli S., Faganeli J., Horvat M. and Brambati A., 2001 - Mercury contamination of coastal sediments as the result of long-term cinnabar mining activity (Gulf of Trieste, northern Adriatic Sea), Applied Geochemistry, 16, 541-558.

5. Eastwood S. and Couture P., 2002 - Seasonal variations in condition and heavy metals concentration of yellow perch (Perca avescens) from a metal contaminated environment, Aquatic Toxicology, 58, 43-56.

6. Eaton A. D., Clescend L. S., Greenberg A. E. and Franson M. A. H., 1995 - Standard method for examination of water and waste water 19th edition, American Public Association (APHA), Washington.

7. Emami Khansari F., Ghazi-Khansari M. and Abdollahi M., 2005 - Heavy metals content of canned tuna fish, Food chemistry, 93, 293-296.

8. FAO/WHO, 1972 - Evaluation of certain food additives and the contaminants mercury, cadmium and lead, WHO Technical report series, 505, Geneva.

9. Fowler S. W., Khan N. Y., Munawwa M. and Price A. R. G., 2002 - The Gulf Ecosystem: Health and Suitability, Bakhuys Publishers, Leyden, Holland.

10. Gaspic Z. K., Zvonaric T., Vrgoc N., Odzak N. and Baric A., 2002 - Cadmium and lead in selected tissues of two commercially important fish species from Adriatic Sea, Water Research, 36, 5023-5028.

11. Gregory G. P., Rajotte J. W. and Couture P., 2005 - Effects of industrial metals on wild fish populations along a metal contamination gradient, Ecotoxicology and Environment, 61, 287312.

12. Hernandez L. M., Gomara B., Fernandez M., Jimenez B., Gonzalez M. J., Baos R., Hiraldo F., Ferrer M., Benito Suner M. A., Devesa V., Munoz O. and Montoro R., 1999 - Accumulation of heavy metals and As in wetland birds in the area around Donana national park affected by the Aznacollar toxic spill, Total Environmental Science, 242, 293-308.

13. Iliopoulo G. J. and Kotsanis N., 2001 - Toxic effects of cadmium and mercury in rainbow trout (Oncorhynchus mykiss): A short-term bioassay, Bulletin of Environmental Contamination Toxicology, 66, 77-85.

14. Khoshnood Z. and Khoshnood R., 2013 - Health risks evaluation of heavy metals in sea food, Transylvanian Review of Systematical and Ecological Research, The Wetlands Diversity, 15.1, 137-144.

15. Kucuksezgin F., Uluturhan E., Kontas A. and Altay O., 2002 - Trace metal concentrations’ in edible fishes from Izmir Bay, Eastern Aegean, Marine Pollution Bulletin, 44, 816-832.

16. Langston W. J. and Spence S. K., 1995 - Biological factors involved in metal concentrations observed in aquatic organisms, in Tessier A. and Turner D. R. (eds), Metal Speciation and Bioavailability in Aquatic systems John Wiley, Chichester.

17. Mansour S. A. and Sidky M. M., 2002 - Ecotoxicological studies: 3 Heavy metals contaminating water and fish from Fayoum, Egypt Food Chemistry, 78, 15-22.

18. Mora S. D., Fowler W. S., Wyse E. and Azemard S., 2004a - Distribution of heavy metals in marine bivalves, fish and coastal sediments in the Gulf and Gulf of Oman, Marine Pollution Bulletin, 49, 410-424. 
19. Mora S. D., Fowler S. W., Wyse E. and Azemard S., 2004b - Distribution of heavy metals in marine bivalves, fish and coastal sediments in Gulf and Gulf of Oman, Marine Pollution Bulletin, 49, 410-424.

20. Olaifa F. G., Olaifa A. K. and Onwude 2004 - Lethal and sub-lethal effects of copper to the African Cat fish (Clarias gariepnus), African Journal of Biomedical Research, 7, 65-70.

21. Pinho A. P., Guimaraes J. R. D., Martins A. S., Costa P. A. S., Olavo G. and Valentin J., 2002 Total mercury in muscle tissue of five shark species from Brazilian offshore waters: effects of feeding habit, sex and length, Environmental Research, Section A, 89, 250-258.

22. Shepperd C. R. C., 1993 - Physical environment of the Gulf revealing to marine pollution overview, Marine Pollution Bulletin, 27, 3-8.

23. Uluturhan E. and Kucuksezgin F., 2007 - Heavy metal contaminants in Red Pandora (Pagellus erythrinus) tissues from the Eastern Aegean Sea, Turkey, Water Research, 41, 1185-1192. 